\title{
Design and Development of 6 Elements Aperture Coupled Feed Planar Array Rectangular Microstrip Patch Antenna for CPE WiMAX Application at $3.3 \mathrm{GHz}$
}

\author{
Yusnita Rahayu ${ }^{1}$, Mohamad Tarmizi Ali $^{2}$ and Tutut Herawan ${ }^{3,4,5}$ \\ ${ }^{1}$ Faculty of Engineering, Department of Electrical Engineering, \\ Universitas Riau, Indonesia \\ ${ }^{2}$ Antenna Research Center (ARC), Microwave Technology Centre (MTC) \\ Faculty of Electrical Engineering, UiTM, Shah Alam, Malaysia \\ ${ }^{3}$ Universitas Negeri Yogyakarta, Indonesia \\ ${ }^{4}$ Universitas Teknologi Yogyakarta, Indonesia \\ ${ }^{5}$ Politeknik Negeri Malang, Indonesia \\ yusnita.rahayu@lecturer.unri.ac.id
}

\begin{abstract}
In this paper, the 6 elements aperture coupled feed planar array rectangular microstrip patch antenna was designed and developed for CPE WiMAX application. This antenna uses aperture coupled feed to improve bandwidth. The proposed antenna is compared to similar design of antenna with microstrip line feed, to justify that the proposed antenna produces broader bandwidth. Both of antennas are designed and simulated by using HFSS simulation software and operated in WiMAX frequency range of $3.3 \mathrm{GHz}$. The 6 elements aperture coupled feed antenna gives an impedance bandwidth of $10.53 \%$, this is broader than the 6 elements microstrip line feed antenna which is only has impedance bandwidth of $6.23 \%$. The measured return loss shows $30 \mathrm{MHz}$ frequency shifted from the simulated result at $3.35 \mathrm{GHz}$. Broad radiation pattern E-plane is achieved for both simulated and measured results.
\end{abstract}

Keywords: CPE WiMAX; Aperture coupled antenna; Array antenna; Microstrip antenna

\section{Introduction}

The Worldwide Interoperability for Microwave Access (WiMAX) is a Broadband Wireless Access (BWA) technology which has high data transfer speed (up to $70 \mathrm{Mbps}$ ) and large access range (up to $50 \mathrm{~km}$ ) [1]. WiMAX is positioned as solution for outdoor and long-range last-mile solutions. It is intended to deliver high speed data communication, and it also has the ability to maintain dedicated links and Voice over IP (VoIP) services at a reliable and high quality speed [2]. WiMAX operates in both licensed and unlicensed spectrum. The WiMAX IEEE 802.16a standard was released in January 2003 with the frequency in use between $2 \mathrm{GHz}$ to $11 \mathrm{GHz}$ [3]. According to Indonesia regulation body, Ministry of Communication and Informatics, No.05/KEP/M.KOMINFO/01/2009, the frequency band used for Wireless Broadband technology is $3.3-3.4 \mathrm{GHz}$ [4]. Antenna plays signifant role in wireless communication. An antenna is a transducer that converts guided electromagnetic energy in a transmission line to radiate electromagnetic energy in free space. Since WiMAX technology was introduced, many researchers have been investigated the antenna design for WiMAX applications. The comparison between WiMAX and WiFi technology has been performed

Received (February 19, 2018), Review Result (April 27, 2018), Accepted (May 30, 2018) 
in [2]. WiMAX supports mobile, nomadic and fixed wireless applications. To access mobile WiMAX network, it is required a Customer Premise Equipment (CPE) in the subscriber station. Research on microstrip antenna for WiMAX application can be found in literature review [5-15]. Microstrip antenna has numerous advantages that it has small size, low fabrication cost, light weight and it can be easily installed on the CPE. Microstrip antenna has very narrow bandwidth. The bandwidth can be improved by aperture coupled feeding technique [16]. Single layer microstrip line feed elements are typically limited to bandwidth of 2-5\%. But aperture coupled antenna provides up to 10$15 \%$ of bandwidth with single layer [17]. Several research papers are found in literature that related to the design of microstrip antenna by using aperture coupled feeding technique. Suryakanth \& Mulgi [18] has designed the rectangular microstrip antenna by using aperture coupled feeding technique for dual band operation. The antenna resonates for two resonant frequencies at $11.36 \mathrm{GHz}$ and $14.26 \mathrm{GHz}$. The impedance bandwidths are found to be $23.87 \%$ and $21.68 \%$, respectively. The similar study was conducted by Nwalozie, et al. [19], where in antenna configuration consisted of 16 array elements. They used aperture coupled feeding for exciting array elements and obtained nearly $11 \%$ of impedance bandwidth. Vishwakarma \& S. Tiwari [20] presented aperture coupled stacked patch antenna using air gap variation, the measured return loss exhibit an impedance bandwidth of $35 \%$ in the frequency range of $2.9 \mathrm{GHz}$ to $6.0 \mathrm{GHz}$. Lai, et al [21] has studied the aperture-coupled microstrip-line feed for circularly polarized patch antenna. The wide impedance and axial ratio bandwidths are achieved by the proposed feeding mechanism.

Other feeding techniques are also proposed by some researchers for WiMAX antenna. A dual-band design of a finite ground coplanar waveguide (CPW) fed antenna for WiMAX was presented by Chitra [8]. Sim \& Lai [9] designed an inverted-F antenna for WLAN/WiMAX dual-network applications. To achieve broad bandwidth, the techniques of shorting the open-end of the microstrip feed line to the driven monopole and loading a C-shaped parasitic element with dissimilar arm lengths into the opposite side of the IFA were introduced. Nishamol et al [10] presented a broadband proximity coupled patch antenna for IEEE802.11a, WiMAX, HIPERLAN2 and HiSWaNa applications. The Vslots and corner notches are employed in a rectangular patch to achieve broadband operation. Other types of WiMAX antennas are listed in [11-13].

Therefore, this paper describes the design and development of rectangular microstrip patch antenna array for the CPE WiMAX which operates at $3.3 \mathrm{GHz}$ band by using aperture coupled feeding technique. Our present work is an extension from our previous paper published in [14]. The simulation is developed in Ansoft HFSS. Comparison between the simulation and measurement results are discussed. Simulation antenna with similar design using microstrip line feed is also done to justify that this proposed feeding technique produced bandwidth is broader than that one.

\section{Design Parameters}

Figure 1 shows an overview of a microstrip patch antenna design with aperture coupled technique. There are two substrates; one for feed line and another for patch are formed. A slot is formed at center of ground and feed line is below the second substrate. These types of antennas are more popular, because of the patches and slots can be any shape and this gives the improvement in the performance of microstrip patch antennas. 


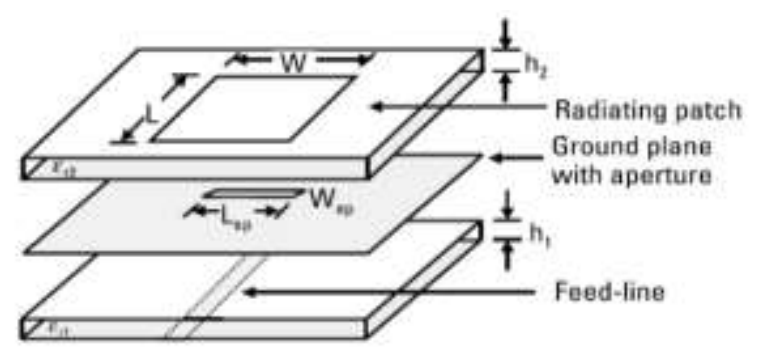

Figure 1. Technique of Aperture Coupled Feed

The simulation is developed in Ansoft HFSS with the specifications shown in the Table 1 below.

Table 1. Array Antenna Specification

\begin{tabular}{|l|l|}
\hline \multicolumn{1}{|c|}{ Features } & \multicolumn{1}{c|}{ Specification } \\
\hline Center Frequency $\left(f_{0}\right)$ & $3.35 \mathrm{GHz}$ \\
\hline $\begin{array}{l}\text { Array Antenna } \\
\text { Configuration }\end{array}$ & 6 Elements Planar Array \\
\hline Microstrip Radiator used & Rectangular Patch Cooper \\
\hline Antenna Gain & $\geq 6 \mathrm{~dB}$ \\
\hline Antenna Impedance BW & $\geq 10 \%$ \\
\hline Input Impedance $\left(\mathrm{Z}_{0}\right)$ & Connector SMA $50 \Omega$ \\
\hline Substrate & FR4 (Epoxy), $\varepsilon_{\mathrm{r}}=4.4$ \\
\hline
\end{tabular}

\subsection{Patch Dimension}

In this design, the patch used is rectangular form that has a width and a length. Equation (1)-(5) is used to calculate the width and length of patch [20].

$$
W=\frac{c}{2 f_{0} \sqrt{\frac{\left(\varepsilon_{r}+1\right.}{2}}}
$$

Equation (1) is used to calculate the width of patch. To determine the length of the patch $(L)$, parameter $\Delta L$ which is the length due to the fringing effect is required. Calculation $\Delta L$ is given by equation (2-3):

$$
\Delta L=0,412 h \frac{\left(\varepsilon_{\text {reff 젠 }} 0,3\right)\left(\frac{W}{h}+0,264\right)}{\left(\varepsilon_{\text {reff 젯 }} 0,258\right)\left(\frac{W}{h}+0,8\right)}
$$

The $\varepsilon_{\text {reff }}$ is the effective dielectric constant is given by:

$$
\varepsilon_{\text {reff }}=\frac{\varepsilon_{r}+1}{2}+\frac{\varepsilon_{r}-1}{2}\left(\frac{1}{\sqrt{1+12\left(\frac{h}{W}\right)}}\right)
$$

Thus the patch length $(L)$ is given by (4-5): 


$$
L_{\text {eff }}=\frac{c}{2 f_{0 \text { 武 }} \sqrt{\varepsilon_{\text {reff }}} \text { ? }}
$$

Where $L_{\text {eff }}$ is the effective length of the patch can be given by:

$$
L=L_{e f f}-2 \Delta L
$$

From the equation above, the width and length of patch obtained are $27.25 \mathrm{~mm}$ and 21 $\mathrm{mm}$, respectively. Size optimization has been done for patch length of antenna design with microstrip line feed. The optimized length is $21.5 \mathrm{~mm}$ instead of $21 \mathrm{~mm}$. the optimized is performed to get center frequency fixed at $3.35 \mathrm{GHz}$.

\subsection{Feed Network}

Feed network is the feed line configuration of array antenna. Feed network consists of $50 \Omega$ feed line and T-junction. The T-junction used has an impedance of $70.71 \Omega$ and 86.6 $\Omega$.

\subsubsection{Calculation of the $50 \Omega$ Feed Line Width (Wf)}

The width of the $50 \Omega$ feed line is given by equation (6) and (7) [22]. From the equations, the feed line width is obtained $3.06 \mathrm{~mm}$.

$$
\begin{gathered}
B=\frac{60 ? \varepsilon_{r}^{2}}{Z_{0} \times \sqrt{\varepsilon_{r}}} \\
W=\frac{2 h}{\pi}\left\{B--\ln (2 B-1)+\frac{\varepsilon_{r}-1}{2 \varepsilon_{r}}\left[\ln (B-1)+0,39-\frac{0,61}{\varepsilon_{r}}\right]\right\}
\end{gathered}
$$

\subsubsection{Calculation of the T-Junction}

This paper uses the T-junction as a power divider [23]. T-junction used has an impedance of $70.71 \Omega$ and $86.6 \Omega$. The width of $\mathrm{T}$ junction $70.71 \Omega$ is given by equation (6) and (7). From the equation, the feed line is $1.6 \mathrm{~mm}$. To calculate the length of the feed line of T junction $70.71 \Omega$ is calculated by the equations (8) to (10):

$$
l=\frac{\lambda_{o}}{4 \sqrt{\varepsilon_{e f f}}}
$$

Where $\varepsilon_{\text {eff }}$ is an effective dielectric constant calculated by the equations:

$$
\begin{gathered}
\frac{W}{h}=\frac{2 h}{\pi}\left\{B--\ln (2 B-1)+\frac{\varepsilon_{r}-1}{2 \varepsilon_{r}}\left[\ln (B-1)+0,39-\frac{0,61}{\varepsilon_{r}}\right]\right\} \\
\varepsilon_{\text {reff }}=\frac{\varepsilon_{r}+1}{2}+\frac{\varepsilon_{r}-1}{2}\left(\frac{1}{\sqrt{1+12\left(\frac{1}{\mathrm{~W} / \mathrm{h}}\right)}}\right)
\end{gathered}
$$

From the calculation, the length of the T junction $70.71 \Omega$ feed is obtained $12.57 \mathrm{~mm}$. In addition, $T$-Junction $86.6 \Omega$ is also used for 3 branching points. By using the same 
equations, the width and length of $T$ junction $86.6 \Omega$ are obtained $0.98 \mathrm{~mm}$ and $12.77 \mathrm{~mm}$, respectively.

\subsection{Aperture Slot}

Design of aperture slot is only used by antenna using aperture coupled feed. The width and length of the slot aperture determined by using equation (6) and (7) [15].

$$
\begin{aligned}
& L_{a}=0,2 \chi_{0}=, 2 \times 89,55=18 ? \mathrm{~mm} \\
& W_{a}=0,1 \mathcal{L}_{a}=, 1 \times 18=1,8 \mathrm{~mm}
\end{aligned}
$$

From the calculation obtained the slot width $\left(W_{a}\right)$ and length $\left(L_{a}\right)$ are $1.8 \mathrm{~mm}$ and 18 $\mathrm{mm}$, respectively. Size optimization has been done for slot aperture length. The optimized length is $20.3 \mathrm{~mm}$ instead of $18 \mathrm{~mm}$. the optimized is performed to get center frequency fixed at $3.35 \mathrm{GHz}$.

In this paper, two antennas design are simulated. One antenna uses aperture coupled feed and the other one uses microstrip line feed. Bandwidth of both antennas will be compared and analyzed. Table 2 is antenna dimensions after optimization.

\begin{tabular}{|c|c|c|c|}
\hline \multirow[b]{2}{*}{ Dimensions } & \multicolumn{3}{|c|}{ Values } \\
\hline & Parameters & $\begin{array}{l}\text { Aperture } \\
\text { Coupled Feed }\end{array}$ & $\begin{array}{l}\text { Microstrip } \\
\text { Line Feed }\end{array}$ \\
\hline \multirow{2}{*}{$\begin{array}{l}\text { Substrate FR-4 } \\
\text { (epoxy) }\end{array}$} & Length $\left(\mathrm{L}_{\mathrm{s}}\right)$ & $140.57 \mathrm{~mm}$ & $140.57 \mathrm{~mm}$ \\
\hline & Width $\left(\mathrm{W}_{\mathrm{s}}\right)$ & $96.02 \mathrm{~mm}$ & $96.02 \mathrm{~mm}$ \\
\hline \multirow{2}{*}{ Patch } & Length $\left(\mathrm{L}_{\mathrm{p}}\right)$ & $21 \mathrm{~mm}$ & $21.5 \mathrm{~mm}$ \\
\hline & Width $\left(\mathrm{W}_{\mathrm{p}}\right)$ & $27.25 \mathrm{~mm}$ & $27.25 \mathrm{~mm}$ \\
\hline \multirow{2}{*}{ Ground Plane } & Length $\left(l_{\mathrm{g}}\right)$ & $140.57 \mathrm{~mm}$ & $140.57 \mathrm{~mm}$ \\
\hline & Width $\left(\mathrm{w}_{\mathrm{g}}\right)$ & $96.02 \mathrm{~mm}$ & $96.02 \mathrm{~mm}$ \\
\hline \multirow{2}{*}{$50 \Omega$ Feed Line } & Length $\left(\mathrm{L}_{50}\right)$ & $20 \mathrm{~mm}$ & $5 \mathrm{~mm}$ \\
\hline & Width $\left(\mathrm{W}_{50}\right)$ & $3.06 \mathrm{~mm}$ & $3.06 \mathrm{~mm}$ \\
\hline \multirow{2}{*}{$\begin{array}{l}\text { T-Junction (86.6 } \\
\Omega)\end{array}$} & $\begin{array}{l}\text { Length } \\
\text { ( L86.6) }\end{array}$ & $12.77 \mathrm{~mm}$ & $12.77 \mathrm{~mm}$ \\
\hline & $\begin{array}{l}\text { Width } \\
\left(\mathrm{W}_{86.6}\right)\end{array}$ & $0.98 \mathrm{~mm}$ & $0.98 \mathrm{~mm}$ \\
\hline \multirow{2}{*}{$\begin{array}{l}\text { T-Junction (70.71 } \\
\Omega)\end{array}$} & $\begin{array}{l}\text { Length( } L_{70.71} \\
\text { ) }\end{array}$ & $12.57 \mathrm{~mm}$ & $12.57 \mathrm{~mm}$ \\
\hline & $\begin{array}{l}\text { Width } \\
\left(\mathrm{W}_{70.71}\right)\end{array}$ & $1.6 \mathrm{~mm}$ & $1.6 \mathrm{~mm}$ \\
\hline \multirow{2}{*}{ Aperture Slot } & Length $\left(\mathrm{L}_{\mathrm{a}}\right)$ & $20.3 \mathrm{~mm}$ & - \\
\hline & Width $\left(\mathrm{W}_{\mathrm{a}}\right)$ & $1.8 \mathrm{~mm}$ & - \\
\hline
\end{tabular}

Table 2. Antenna Dimensions after Optimization

\subsection{Antenna Geometry}

Figure 2 shows the 6 elements aperture coupled feed planar array rectangular microstrip patch antenna prototype that has been developed. This antenna is designed using two FR-4 (epoxy) substrates having $1.6 \mathrm{~mm}$ thickness (h) and 4.4 dielectric constant $\left(\varepsilon_{\mathrm{r}}\right)$. The gap between the substrate-1 and substrate- 2 is $3 \mathrm{~mm}$. Radiating elements (patch) are etched on the top surface of the substrate-1. Usually in array configuration, spacing between two radiating elements is kept at a distance $\lambda_{\mathrm{o}} / 2$. The network feed is etched 
below the substrate-2 as shown in Figure 2(b) having thickness (h) and dielectric constant $\left(\varepsilon_{\mathrm{r}}\right)$ as that of substrate-1. The network feed consists of the $50 \Omega$ feed line and T-Junction. The $50 \Omega$ feed line has the length of $20 \mathrm{~mm}$ after it was optimized. The aperture slots are placed on the top surface, which is the ground plane of the substrate- 2 exactly at the below center of the radiating elements. The aperture slot has $20.3 \mathrm{~mm} \times 1.8 \mathrm{~mm}$ size after it was optimized. The substrate- 2 is placed below the substrate- 1 that forms aperture coupled feed. The radiating elements are placed on the top surface of substrate- 1 shown in Figure 2(a) energizes through coupling slots. The SMA connector is used at the tip of 50 $\Omega$ feed line for feeding the microwave power.

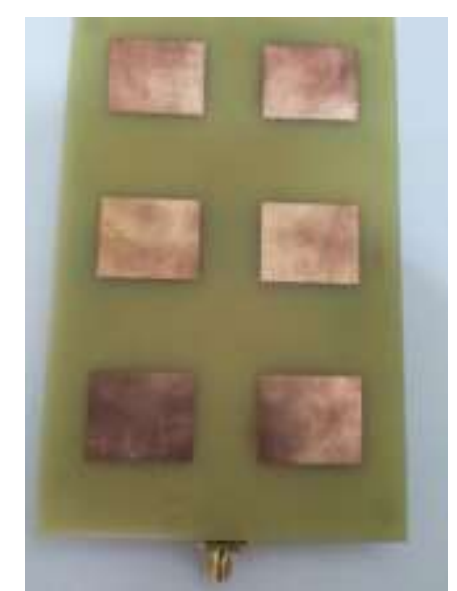

(a) Top View of Substrate-1

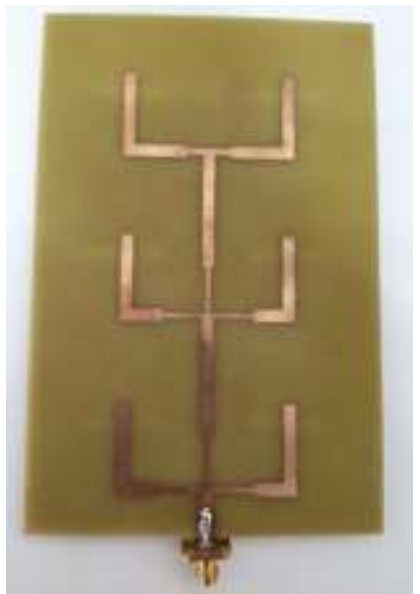

(b) Bottom View of Substrate-2

\section{Figure 2. Prototype of 6 Elements Aperture Coupled Feed Planar Array Rectangular Microstrip Patch Antenna}

Figure 3 shows geometry of 6 elements microstrip line feed planar array rectangular microstrip patch antenna. This antenna was designed using one substrate. The radiating elements and network feed are etched on the top surface of the substrate. The ground plane is placed below of the substrate. The spacing between two radiating elements and network feed are used same with antenna using aperture coupled feed. But the $50 \Omega$ feed line has the length of $5 \mathrm{~mm}$ and then length of radiating element is $21.5 \mathrm{~mm}$ after it was optimized.

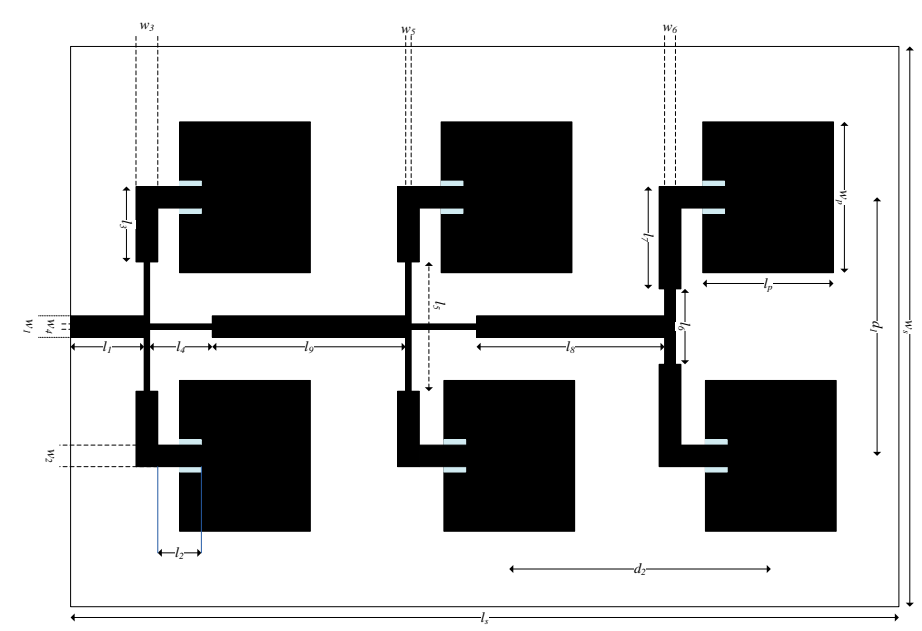

Figure 3. Geometry of both Microstrip Feed Line and Electromagnetically Coupling Feed 


\section{Results and Analysis}

VSWR simulation results for both antennas design with different feeding techniques are shown in Figure 4. It shows that the antenna operates at 3.3-3.4 GHz. Both antennas provide well matched VSWR at the desired frequencies.

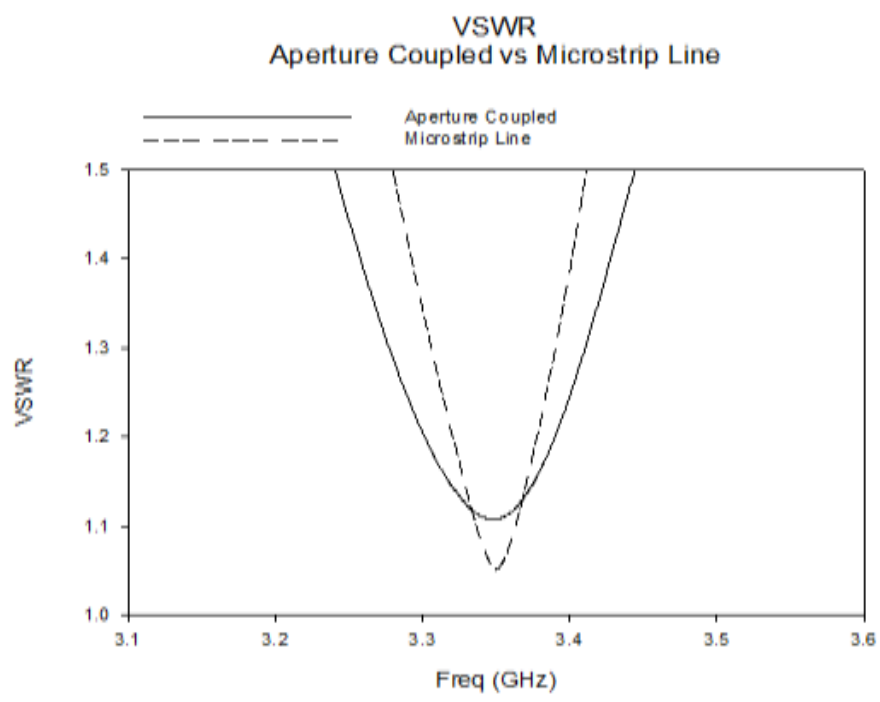

Figure 4. VSWR Simulation Results for Aperture Coupled and Microstrip Feed Line Techniques

The impedance bandwidth is calculated using the following formula [24]:

$$
\text { Bandwidth }=\frac{f_{2}-f_{1}}{f_{c}} \times 100 \%
$$

Where, $f_{2}$ and $f_{1}$ are higher and lower cut-off frequency of the band respectively, when its return loss reaches $\leq-10.16 \mathrm{~dB}(\mathrm{VSWR} \leq 1.9)$ and $f_{c}$ is the center frequency of this band. Comparison of bandwidth for both antennas design, using aperture coupled feed and microstrip line feed, is given in Table 3.

Table 3. Comparison of Antenna Bandwidth

\begin{tabular}{|l|c|c|c|c|c|}
\hline \multicolumn{1}{|c|}{ Antenna } & \multirow{2}{*}{$\begin{array}{c}\text { Lower } \\
\text { Frequency } \\
(\mathbf{G H z})\end{array}$} & $\begin{array}{c}\text { Higher } \\
\text { Frequency } \\
(\mathbf{G H z})\end{array}$ & $\begin{array}{c}\text { Center } \\
\text { Frequency } \\
(\mathbf{G H z})\end{array}$ & \multicolumn{2}{|c|}{ Bandwidth } \\
\cline { 5 - 6 } & $\mathbf{M H z}$ & $\mathbf{\%}$ \\
\hline $\begin{array}{l}\text { 6 Elements microstrip line feed } \\
\text { planar array rectangular } \\
\text { microstrip patch antenna }\end{array}$ & 3.236 & 3.444 & 3.34 & 208 & 6.23 \\
\hline $\begin{array}{l}\text { 6 Elements aperture coupled feed } \\
\text { planar array rectangular } \\
\text { microstrip patch antenna }\end{array}$ & 3.18 & 3.5335 & 3.3568 & 353.5 & 10.53 \\
\hline
\end{tabular}

Table 3 presents the 6 elements microstrip line feed planar array rectangular microstrip patch antenna having an impedance bandwidth of $208 \mathrm{MHz}(6.23 \%)$. And then the 6 elements aperture coupled feed planar array rectangular microstrip patch antenna gives wider impedance bandwidth $(10.53 \%)$ when compared to antenna using microstrip line feed. The 6 elements aperture coupled feed planar array rectangular microstrip patch antenna achieves bandwidth of $10 \%$ which is usually bandwidth obtained single element 
antenna using aperture coupled feed. Figure 5 shows the gain of each antenna versus frequency. Gain of 6 elements aperture coupled feed planar array rectangular microstrip patch antenna at $3.4 \mathrm{GHz}$ is $8.4327 \mathrm{dBi}$. This gain has achieved the required specification ( $\geq 6 \mathrm{dBi}$ ). This antenna gain is higher compared to the gain of 6 elements microstrip line feed antenna which is only $3.8805 \mathrm{dBi}$. Aperture coupled antenna is able to decrease surface wave thus improves the gain.

Gain vs Frequency

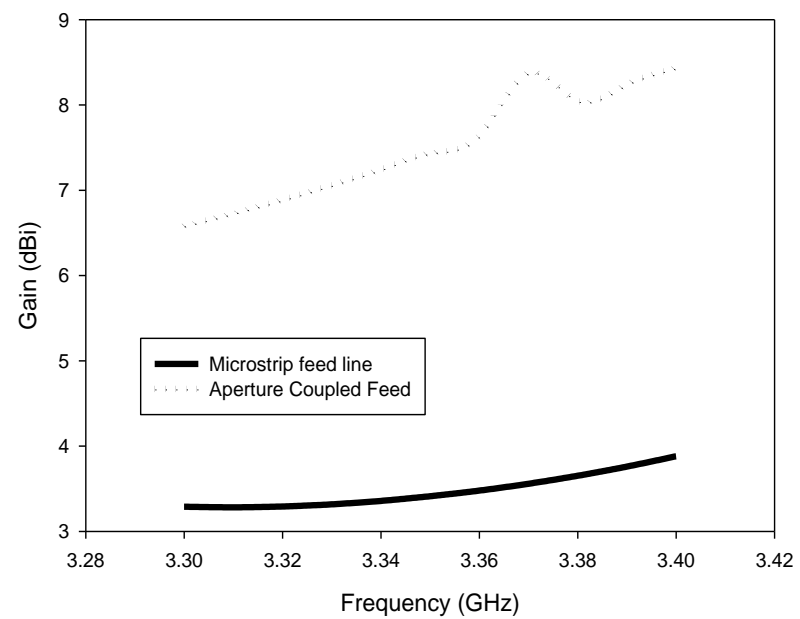

Figure 5. Gain of Antennas

Characteristics of various length of feed line and dimension of aperture slot that affect to the return loss is depicted in Figure 6 and Figure 7, respectively. The effect of various length of $50 \Omega$ feed line to the 6 elements aperture coupled feed planar array rectangular microstrip patch antenna is shown in Figure 6. It shows that the feed length of $20 \mathrm{~mm}$ provides $-44 \mathrm{~dB}$ of return loss. This is the best return loss compared to other feed line length.

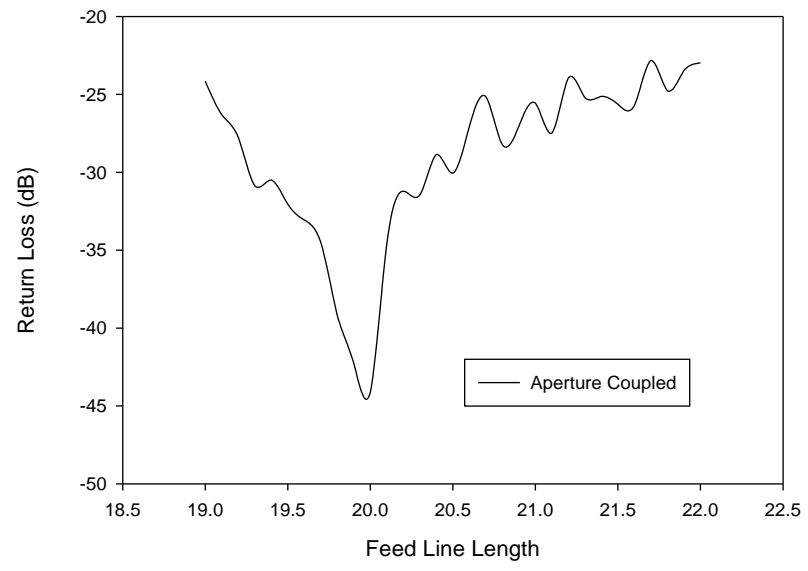

Figure 6. Feed Line Length vs Return Loss 


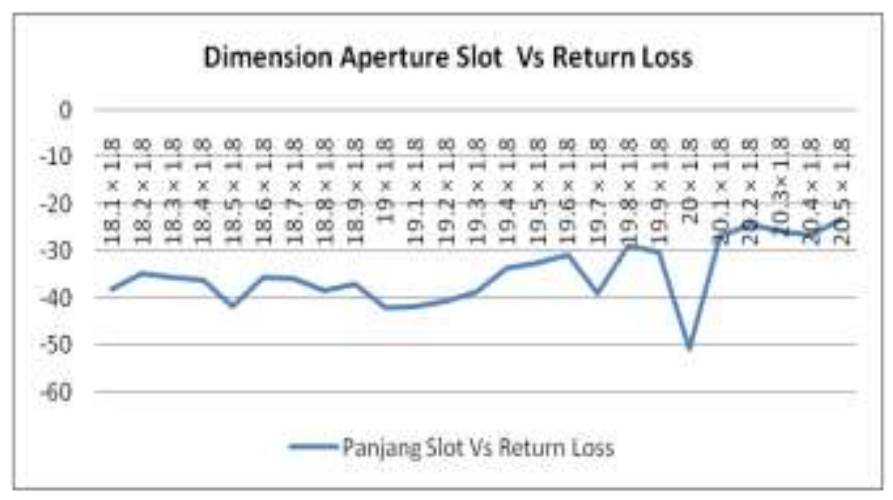

Figure 7. Dimension Aperture Slot vs Return Loss

Figure 7 shows the effect of dimension aperture slot to the return loss. The dimension aperture slot of $20.3 \times 1.8 \mathrm{~mm}$ provides the return loss of $-25.84 \mathrm{~dB}$ at $3.35 \mathrm{GHz}$. But, the dimension of $20 \times 1.8 \mathrm{~mm}$ gives the return loss of $-50.75 \mathrm{~dB}$ at $3.28 \mathrm{GHz}$. The antenna measurement setup in anechoic chamber is shown in Figure 8. Radiation pattern E-plane is measured for each $10^{\circ}$ phase shift at $3.3 \mathrm{GHz}$. Horn antenna is used as antenna reference.

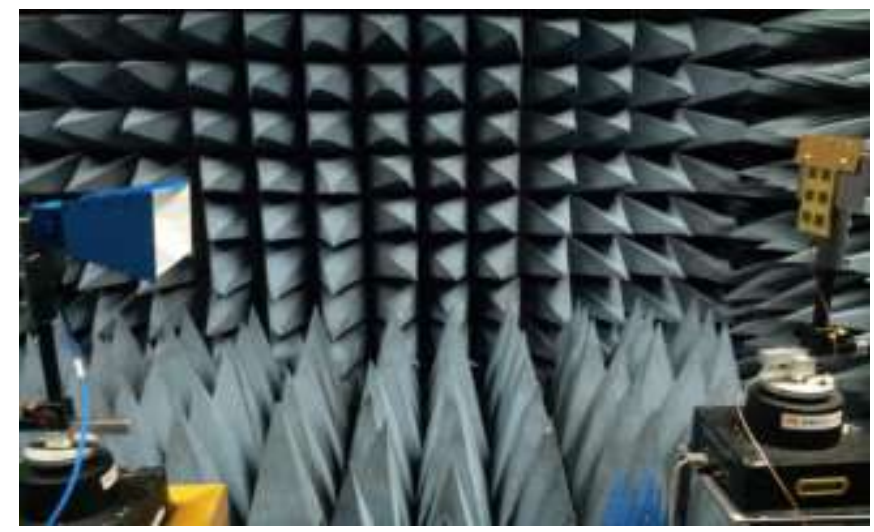

Figure 8. Antenna Measurement Setup in Anechoic Chamber

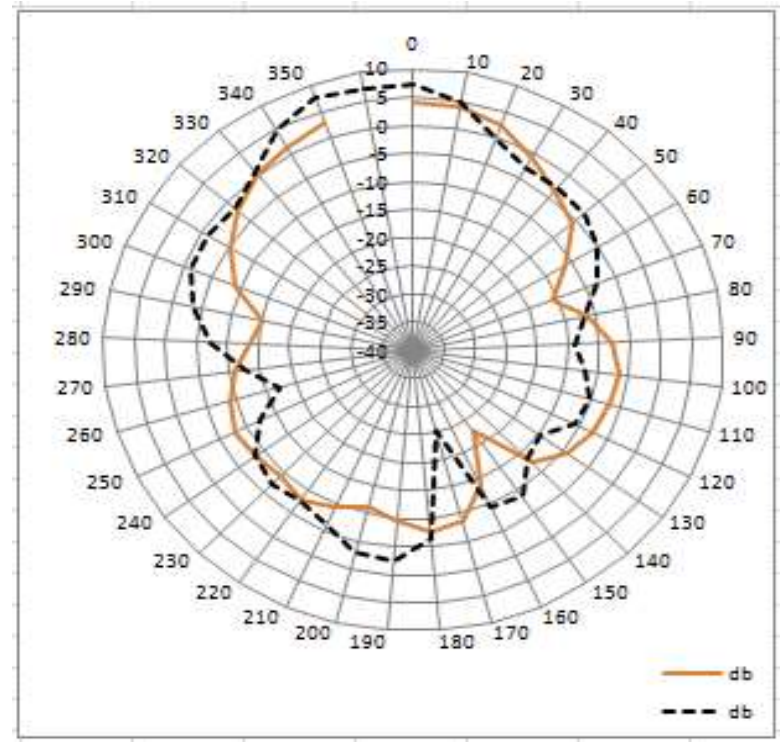

Figure 9 Simulated and Measured Radiation Patterns 
The simulated and measured radiation pattern of 6 elements aperture coupled feed planar array rectangular microstrip patch antenna is shown in Figure 9. The measured radiation pattern is shown by solid line and the simulated radiation pattern is shown in dashed line. Both results are almost similar. Comparison return loss for both antennas design with different feeding techniques is performed in Figure 10.

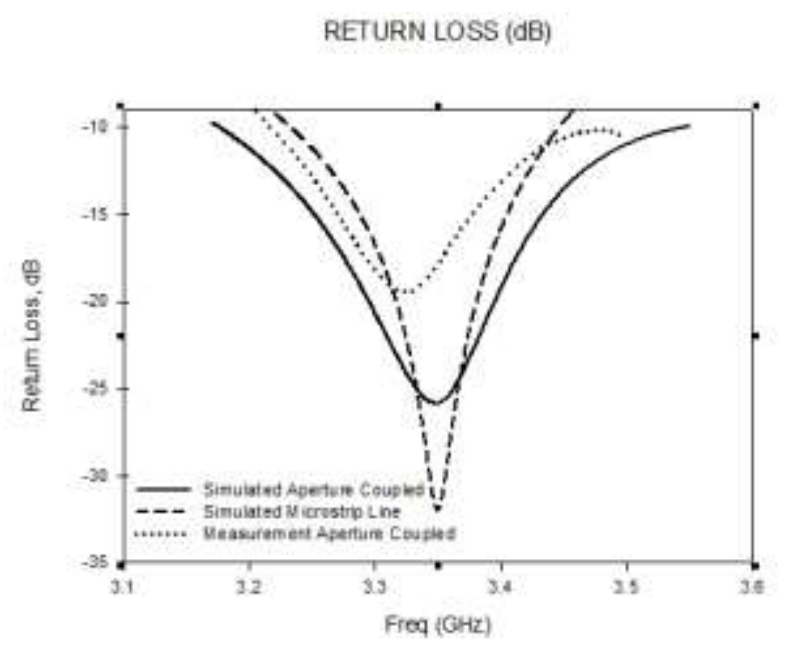

Figure 10. Simulated and Measured Return Loss

From Figure 10, the simulated and measured return loss for 6 element aperture coupled feed planar array rectangular microstrip patch antenna are also been done. It is shown that the maximum return loss for antenna with microstrip line feed is achieved at $-32 \mathrm{~dB}$ of $3.35 \mathrm{GHz}$. The maximum return loss for antenna with aperture coupled feed is $-25.8 \mathrm{~dB}$ at $3.35 \mathrm{GHz}$, while for measured return loss is $-19.38 \mathrm{~dB}$ at $3.32 \mathrm{GHz}$ and $-17.77 \mathrm{~dB}$ at 3.35 GHz. There is frequency shifted such $30 \mathrm{MHz}$ between simulated and measured result but both results are consider good.

\section{Conclusions}

Design and development of 6 elements aperture coupled feed planar array rectangular microstrip patch antenna operating at 3.3 to $3.4 \mathrm{GHz}$ is successfully performed. Both simulated and measured results are almost similar. There is $30 \mathrm{MHz}$ frequency shifted between simulated and measured return loss. Broad radiation pattern is achieved for both results. The antenna using microstrip line feed is simulated and analysed. It is shown that the microstrip antenna using aperture coupled feed has an impedance bandwidth of 353.5 $\mathrm{MHz}(10.53 \%)$. This antenna has broader bandwidth than antenna using microstrip line feed $(6.23 \%)$. This antenna has compact in size of about $15 \times 10 \mathrm{~cm}$ and suitable on the CPE WiMAX device.

\section{Acknowledgment}

The author would like to thank for the supports from ARC Lab, UiTM Malaysia for providing the lab measurement facilities and testing.

\section{References}

[1] G. Jindal and V. Grover, "Voice and Video over the WiMAX", International Journal for Computer Application and Research (IJCAR, ISSN: 2320 -5067), vol. special issue 1, (2013) February, pp. 18-25.

[2] A. F. M. Sultanul Kabir, Md. R. Hayat Khan, A. Ahsan Md. Mahmudul Haque and M. Saiful Islam Mamun, "WiMAX or Wi-Fi: The Best Suited Candidate Technology for Building Wireless Access Infrastucture", Cornell University Library, [Online], Available: www.arxiv.org, (2012). 
[3] M. Didarul Alam, S. Chowdhury and S. Alam, "Performance Evaluation of Different Frequency Bands of WiMAX and their Selection Procedure", International Journal of Advanced Science and Technology, Vol. 62, pp. 1-18, (2014).

[4] Minister of Communication and Information, "Decision of the Minister of Communication and Information No: 05/KEP/M.KOMINFO/01/2009 About Determination of Radio Frequency Band Blocks and Wireless Broadband Service Zones on the $3.3 \mathrm{GHz}$ Radio Frequency Band for Existing Radio Frequency Band Users for Wireless Broadband Service Requirement”, [Online]. Available: http:// publikasi.kominfo.go.id/handle/54323613/61, (2009).

[5] H.-W. Liu, C.-H. Ku and C.-F. Yang, "Novel CPW-Fed Planar Monopole Antenna for WiMAX/WLAN Applications", IEEE Antenna and Wireless Propagation Letter, vol. 9, pp. 240-243, (2010) March 08.

[6] H. Zhai, Z. Ma, Y. Han and C. Liang, "A Compact Printed Antenna for Triple-Band WLAN/WiMAX Applications", IEEE Antenna and Wireless Propagation Letter, vol. 12, (2013) January 09, pp. 65-68.

[7] J. Pei, A.-G. Wang, S. Gao and W. Leng, "Miniaturized Triple-Band Antenna With a Defected Ground Plane for WLAN/WiMAX Applications", IEEE Antenna and Wireless Propagation Letter, vol. 10, (2011) April 07, pp. 298-301.

[8] R. J. Chitra, "Design of Double L-Slot Microstrip Patch Antenna for WiMAX and WLAN application", In Proc. Of International Conference on Computing Communication and Applications (ICCCA), IEEE, (2012) February 22-24, pp. 1-4.

[9] C. Y. D. Sim and Y. N. Lai, "An inverted-F antenna design for WLAN/WiMAX dual-network applications", International Journal of RF and Microwave Computer-Aided Engineering, vol. 24, (2013), pp. 523-528.

[10] M. S. Nishamol, V. P. Sarin, D. Tony, C. K. Aanandan, P. Mohanan and K. Vasudevan, "A Broadband Microstrip Antenna for IEEE802.11A /WiMAX/ HIPERLAN2 Applications", Progress in Electromagnetics Research Letters, vol. 19, (2010), pp. 155-161.

[11] R. Saranya and K. RamPrakash, "Design of Reconfigurable Antenna Array for WLAN and WiMAX application”, In Proc. of International Conference on Man-Machine (ICoMMS), pp. 3A1-3A4, (2009) October 11-13.

[12] M. A. Islam, S. Kumar Saha and M. Masudur Rachman, "Dual U-Shape Microstrip Patch Antenna Design for WiMAX Application", International Journal of Science, Engineering and Technology Research (IJSETR)(ISSN:2278-7798, vol. 2, (2013) February.

[13] A. S. Azini, M. R. Kamarudin, T. A. Rahman, H. U. Iddi, A. Y. Abdulrahman and M. F. Jamnlos, "Transparent Antenna Design for WiMAX Application", Progress in Electromagnetics Research, vol. 138, (2013), pp. 133-141.

[14] Y. Rahayu and R. Ananda Gusma, "Simulation of 6 Elements Aperture Coupled Feed Planar Array Rectangular Microstrip Patch Antenna for CPE WiMAX Application at 3.3 GHz”, In Proc. of EECSI, (2014) August 20-21.

[15] A. Hanafi Rambe, "Design of 4 Elements Planar Array Rectangular Microstrip Patch Antenna for WiMAX CPE Applications", Graduate Thesis, University of Indonesia, Indonesia, (2008).

[16] M. Kaur, A. Kaur and K. Rajesh, "A Microstrip Patch Antenna with Aperture Coupler Technique At 5.8 GHz \& 2 GHz”, International Journal of Modern Engineering Research (IJMER), vol. 03, no. 01, (2013) January-February, pp. 587-594.

[17] S. Chakraborty, B. Gupta and D. R. Poddar, "Development of Closed Form Design Formulae for Aperture Coupled Microstrip Antenna”, JSci Ind Res (India), vol. 64, (2005), pp. 482.

[18] B. Suryakanth and S. N. Mulgi, "Design and Development of Aperture Coupled Rectangular Microstrip Antenna for Dual Band Operation", International Journal of Advanced Research in Electrical, Electronics and Instrumentation Engineering (IJAREEIE, ISSN: 2278-8875), vol. 2, (2013) August, pp. 3607-3613.

[19] G. C. Nwalozie, V. N. Okorogu, A. C. Okafor and V. E. Oweh, "Simulation Implementation of Microstrip Antenna Array for $1.8 \mathrm{GHz}$ Band with $10 \mathrm{~dB}$ Gain", International Journal of Emerging Technology and Advanced Engineering (IJETAE), vol. 02, no. 12, (2012) December.

[20] R. Kumar Vishwakarma and S. Tiwari, "Aperture Coupled Stacked Patch Antenna for Dual Band", International Journal of Electronics and Computer Science Engineering (IJECSE, ISSN: 2277-1956), vol. 01, no. 03, (2012), pp. 933-939.

[21] H. Wah Lai, K. Ming Mak and K. Fai Chan, "Novel Aperture-Coupled Microstrip-Line Feed for Circularly Polarized Patch Antenna", Progress in Electromagnetics Research, vol. 144, (2014), pp. 1-9.

[22] J. R. James and P. S. Hall, "Handbook of Microstrip Antennas", vol. I and II. Peter Pergrinus, IEEE, (1989).

[23] D. M. Pozar, "Microwave Engineering", John Willey and Sons, (1997).

[24] S. N. Mulgi, G. M. Pushpanjali, R. B. Konda, S. K. Satnoor and P. V. Hunagund, "Broadband Aperture Coupled Equilateral Triangular Microstrip Array Antenna", Indian Journal of Radio \& Space Physics, vol. 38, (2009) June, pp. 174-179. 
International Journal of Advanced Science and Technology

Vol.117 (2018) 